\title{
Students' perspective towards online proctoring in exams during COVID-19
}

\author{
A.M. Mutawa* and Sai Sruthi \\ Computer Engineering Department, Kuwait University, Kuwait \\ *Corresponding Author:dr.mutawa@gmail.com
}

Submitted :07/07/2021

Revised : :10/10/2021

Accepted :25/10/2021

\begin{abstract}
The World Health Organization (WHO) declared COVID-19 as a pandemic in early 2020. As a result, the organization has decided to close all educational institutions, and thereby, conventional classroom learning has become obsolete. And as a consequence, exams taken online have become an essential part of an online assessment. The critical issue that arises is how to maintain online exam credibility and student honesty during online exams. In this work, we study the acceptance of online exams by Kuwait University students exposed to online proctoring during the lockdown. We proposed an acceptance model based on the TAM framework but with twelve constructs applied to three proctoring methods: AI proctoring, live human proctoring, and blended proctoring. The data is collected using an online survey from 478 college students. The partial least square structural equation modeling (PLS-SEM) method is used to process the collected data. The findings indicate that live-human and mixed proctoring provide a greater level of satisfaction than AI proctoring alone.
\end{abstract}

Keywords: E-learning; Online exam; Online learning; Online proctoring; Technology acceptance.

\section{INTRODUCTION}

The world is still affected by the COVID-2019 pandemic, which began in China and spread rapidly to other countries (Organization, 2020). And after one academic year, many countries started to adapt to the new normal. As a preventative measure, WHO has taken few measures, including sanitation, self-isolation, social distancing, and quarantine. Many educational institutions have shifted to online learning as a result of the COVID-19 pandemic. Universities started using online proctoring tools to administer online exams. However, there are some disadvantages to using online proctoring misconduct or cheating during the online exam, which is one of the most significant obstacles. Therefore, there is a need to provide guidelines for the online proctoring approach for both the students and teachers to maintain ethical standards and academic integrity (Sando et al., 2021).

During the pandemic, an online exam played an essential role in an E-learning ecosystem. The proper design of online assessments plays a significant role in their effectiveness. Online exams are typically performed on a learning management system (LMS) without the physical participation of students and teachers in the exact physical location (Muzaffar et al., 2021). There are many solutions available in the market that provide online proctoring, such as Respondus monitor, Proctorio, B virtual, Loyalist, and ProctorU, to mention a few. They all share the concept of 
offering some sort of tracking and monitoring students during the online exam. Some solutions have added features such as authenticating the student's ID and monitoring any misconduct using AI tools (Foster \& Layman, 2013).

We analyzed the three proctoring methods used in several colleges at Kuwait University (KU) as follows:

i. Live human proctoring: this is a synchronous proctoring method. The instructor asks the students to be on the webcam during the exam.

ii. AI proctoring: in this proctoring method, the instructor uses proctoring tools provided by KU such as Respondus monitor, Proctorio, or Lockdown browsers to monitor the students. This method is asynchronous, where the instructor can check and review the recorded videos only after the exam is finished.

iii. Blended proctoring: this method is a combination of both live human proctoring and AI proctoring.

This paper proposes an online proctoring acceptance model (OPAM) for evaluating Kuwait University students' satisfaction and preference towards online proctoring. We will collect data from students whether they have been exposed to any of the three types of online monitoring, namely, human-based, AI base, or a mixture of both. The data is collected and then processed using the PLS-SEM method with the aid of Smart-PLS software (Sarstedt \& Cheah, 2019). Online exam anxiety test is also performed (Driscoll, 2007). Our research objectives are summarized as follows:

i. To examine and assess students' success and satisfaction with online proctoring.

ii. To assess students' test anxiety and proclivity for misbehavior during online exams.

iii. To discuss various steps that may be used to prevent cheating on an online exam.

\section{LITERATURE REVIEW}

During the COVID-19 pandemic, online exams have become increasingly popular for evaluating students' knowledge. Hence, the use of online proctoring tools also increased to a more significant extent. Due to the lack of face-to-face contact, proctoring online exams is challenging ( $\mathrm{Li}$ et al., 2021). Li and others suggest using visual analytics to achieve effortless, effective, and accurate online proctoring. As technology advances, full adoption of online learning strengthens students' attitudes toward learning. However, there is an issue with cheating in the online exam that needs to be investigated further (Vazquez et al., 2021). Vazquez and others conducted a study of students who took proctored and unproctored exams and discovered that students performed better on face-to-face exams than online proctored exams. A significant limiting factor in maintaining the credibility of the exam and providing unbiased results is efficiently proctoring online remote examinations (Kamble \& Ghorpade, 2021). Human proctoring is another choice for online exam proctoring (Mutawa \& Sruthi 2021). The critical issue is finding a good angle for the students' web camera while taking the exam. There is a risk of cheating during the students' exam if the camera is not positioned correctly (Stapleton \& Blanchard, 2021). Tiong and Lee used deep learning (DL) algorithms to monitor and analyze the students' IP addresses and correlate with students' behavioral changes. When using their DL method, effective results were shown in detecting and preventing cheating during online exams (Tiong \& Lee, 2021).

The online exams started in many courses with the development of technology before COVID-19. Many Universities and Colleges prefer online exams with the help of proctoring tools (Ismail et al., 2019). Academic dishonesty is unavoidable at each stage of student assessment. Many studies concluded that cheating occurs mainly in the unproctored environment, while other studies reported the increases in the proctored environment (Dendir \& Maxwell, 2020; Gamage et al., 2020; Ikram \& Rabbani, 2021). Using measures like providing no extra time, reducing multiple-choice questions, randomizing question patterns, and using plagiarism checkers with proctoring tools can 
reduce cheating to some extent (Goldberg, 2021). Other challenges that students face during online proctoring are browser incompatibility, anxiety for the online exam, and slow internet connection (Alkamel et al., 2021; Cahapay, 2021). Exam anxiety among students can be reduced with proper counseling and a more user-friendly technology interface (Arora et al., 2021; Woldeab \& Brothen, 2019). Before implementing online assessment, governments and institutions should provide the policy to students to maintain reliability. Also, support needs to be provided if technical problems were encountered (Ali \& Al Dmour, 2021). The exam time and scores obtained are different, according to the research conducted by Howard (Howard, 2020). For online unproctored exams, it took a long time for students to complete the test. It can be due to cheating during the exam.

Many software tools provide the necessary facilities like security, copy/past control, and single monitor permission to detect and prevent cheating during online exams. Proctoring software makes the proctor's job more effective, as it can be easily integrated with LMS (Slusky, 2020). With growing technological skills, students are well prepared for the online learning experience.

Generally, there are different types of proctoring; the most familiar are live proctoring and automated proctoring. The automated method, which uses AI for proctoring, is more convenient to some teachers as it does not require any human proctor interaction (Hussein et al., 2020). This approach is comfortable for students because no one monitors them on the opposite side like the live-human method. Also, the software includes recordings, where the instructors can later check for any violation occurrence. Students have a positive attitude towards online proctoring when it does not affect their academic performance (Davis et al., 2016; Hollister \& Berenson, 2009; Weiner \& Hurtz, 2017). Le Corff and others reported that, when comparing five personality traits with an unproctored online test and proctored paper test, the acceptance for both the method is equivalent (Le Corff et al., 2017). However, academic integrity should be maintained in both testing methods (Chuang et al., 2015; Medina \& Castleberry, 2016). According to the instructors' perspective on proctoring methods, students who tended to cheat during an exam would do so.

Researchers also used the technology acceptance model (TAM) to measure the satisfaction of e-learning. Specific hypotheses were tested and evaluated for the quality and effectiveness of e-learning (Salimon et al., 2021). Other researchers use the value-based adoption model (VAM), which measures the acceptance of e-learning (AlMaroof et al., 2021). PLS-SEM is used to process data using these models (Hair Jr et al., 2014). With the SEM model, the management in higher education can easily understand the E-learning effectiveness based on the perspective of students and the influence of technology on them (Fattah \& Setyadi, 2021; Shahzad et al., 2021).

\section{PROPOSED FRAMEWORK}

Our framework or model consists of 12 constructs consisting of eight dependent and four independent constructs. We adopted the technology acceptance model (TAM) as the base model (Lee et al., 2003) and extended the work of Mutawa \& Sruthi (2021) by applying blended proctoring as well as human online and AI proctoring. A set of hypotheses is formed connecting these twelve constructs. For each construct, there are specific indicators, which help check the validity and reliability of the model. Figure 1 depicts the proposed OPAM framework. 


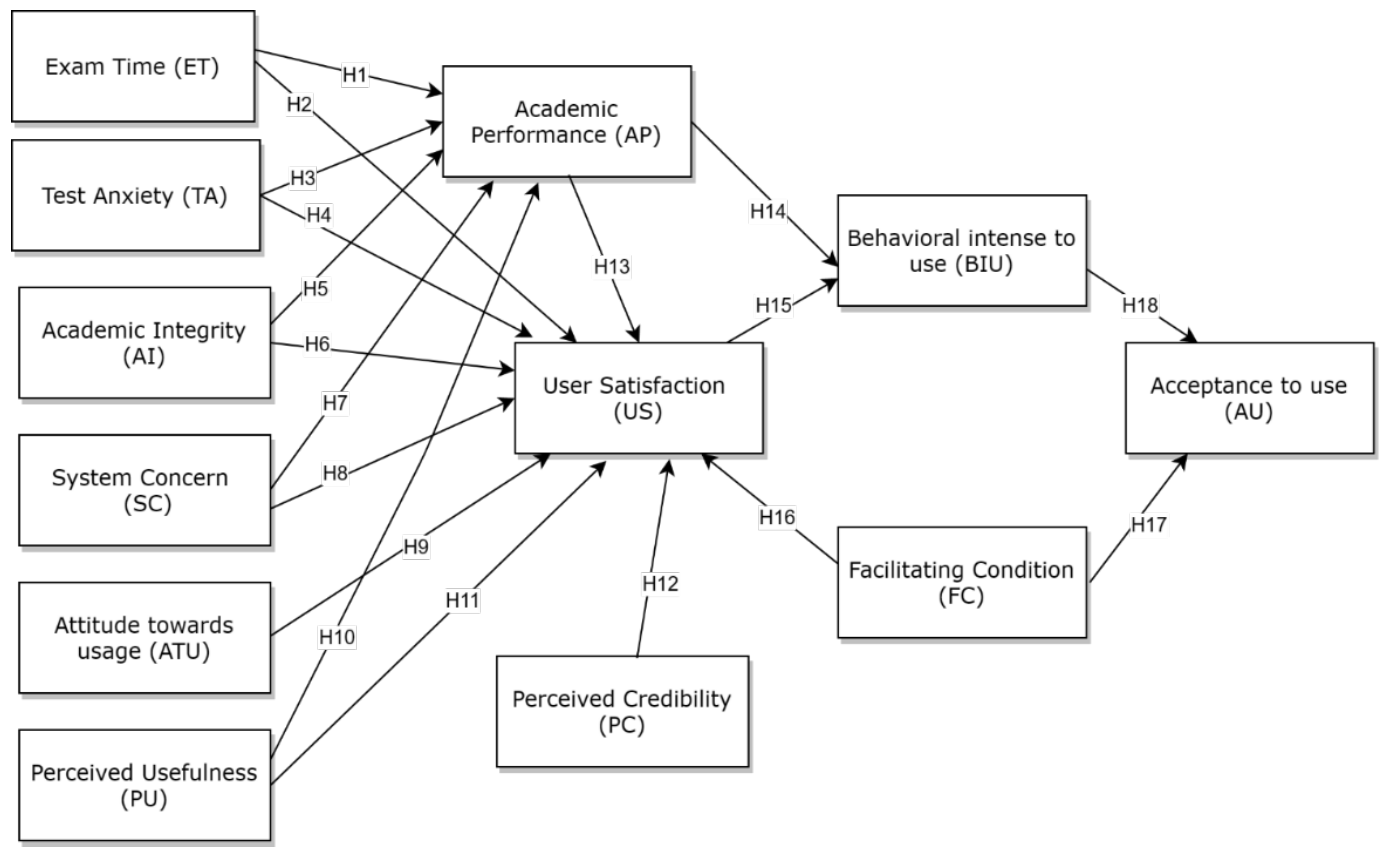

Figure 1. Our proposed OPAM framework.

\section{Constructs and Hypotheses}

The constructs and corresponding hypotheses are shown in Table 1.

Table 1. The constructs and corresponding hypothesis.

\begin{tabular}{|c|l|l|}
\hline Constructs & \multicolumn{1}{|c|}{ Hypothesis } & Usage and corresponding indicators \\
\hline $\begin{array}{c}\text { Exam Time } \\
\text { (ET) }\end{array}$ & $\begin{array}{l}\text { Hypothesis 1 (H1): Exam time has a beneficial } \\
\text { impact on students' academic performance } \\
\text { during a proctored online exam. } \\
\text { Hypothesis 2 (H2): Exam time has a beneficial } \\
\text { impact on students' satisfaction while using } \\
\text { the proctoring tool. }\end{array}$ & $\begin{array}{l}\text { ET deals with students' perceptions of } \\
\text { the amount of time they spent on the } \\
\text { online exam with proctoring. It has } \\
\text { three indicators, ET1, ET2, and ET3, } \\
\text { which ask the students about the online } \\
\text { exam time with proctoring. }\end{array}$ \\
\hline Test Anxiety \\
(TA) & $\begin{array}{l}\text { Hypothesis 3 (H3): Test anxiety has a } \\
\text { beneficial impact on students' academic } \\
\text { performance during online exams. } \\
\text { Hypothesis 4 (H4): Test anxiety has a } \\
\text { beneficial impact on students' satisfaction } \\
\text { while using the proctoring tool. }\end{array}$ & $\begin{array}{l}\text { TA mentions the anxiety of students } \\
\text { during the online exam. We followed } \\
\text { the Westside Test Anxiety scale to } \\
\text { measure the level of anxiety (Driscoll, } \\
\text { 2007). The indicator is TA1. }\end{array}$ \\
\hline
\end{tabular}




\begin{tabular}{|c|c|c|}
\hline $\begin{array}{l}\text { Academic } \\
\text { Integrity } \\
\text { (AI) }\end{array}$ & $\begin{array}{l}\text { Hypothesis } 5 \text { (H5): Academic integrity has a } \\
\text { beneficial impact on students' academic } \\
\text { performance by minimizing cheating. } \\
\text { Hypothesis } 6 \text { (H6): Academic integrity has a } \\
\text { beneficial impact on students' satisfaction } \\
\text { towards the proctoring method by minimizing } \\
\text { cheating. }\end{array}$ & $\begin{array}{l}\text { AI refers to the cheating or misconduct } \\
\text { that can happen when moving the } \\
\text { exams online. The indicators are AI1, } \\
\mathrm{AI} 2, \mathrm{AI} 3, \mathrm{AI} 4, \text { and AI5. These } \\
\text { indicators are the questions that are } \\
\text { asked to students in the survey. }\end{array}$ \\
\hline $\begin{array}{l}\text { System } \\
\text { Concern } \\
\text { (SC) }\end{array}$ & $\begin{array}{l}\text { Hypothesis } 7(\mathrm{H} 7) \text { : System concern has a } \\
\text { beneficial impact on students' academic } \\
\text { performance during the online exam. } \\
\text { Hypothesis } 8(\mathrm{H} 8) \text { : System concern has a } \\
\text { beneficial impact on students' satisfaction } \\
\text { towards using the proctoring tool. }\end{array}$ & $\begin{array}{l}\text { SC refers to the technical problems for } \\
\text { students when dealing with the online } \\
\text { exam with proctoring. It has three } \\
\text { indicators, } \mathrm{SC} 1, \mathrm{SC} 2 \text {, and } \mathrm{SC} 3 \text {. }\end{array}$ \\
\hline $\begin{array}{c}\text { Attitude } \\
\text { towards } \\
\text { usage (ATU) }\end{array}$ & $\begin{array}{l}\text { Hypothesis } 9 \text { (H9): Students' satisfaction with } \\
\text { the proctoring tool is influenced by their } \\
\text { attitude towards its usage. }\end{array}$ & $\begin{array}{l}\text { ATU refers to the students' attitude } \\
\text { towards using the proctoring tool. It } \\
\text { consists of four indicators, ATU1, } \\
\text { ATU2, ATU3, and ATU4. }\end{array}$ \\
\hline $\begin{array}{l}\text { Perceived } \\
\text { Usefulness } \\
\quad \text { (PU) }\end{array}$ & $\begin{array}{l}\text { Hypothesis } 10 \text { (H10): Perceived usefulness } \\
\text { positively impacts students' academic } \\
\text { performance. } \\
\text { Hypothesis } 11 \text { (H11): Perceived usefulness } \\
\text { positively impacts students' satisfaction } \\
\text { towards using the proctoring tool. }\end{array}$ & $\begin{array}{l}\text { PU is about students' perspectives on } \\
\text { using the proctoring tool and their } \\
\text { belief that using the tool will improve } \\
\text { their academic grades. PU1, PU2, PU3, } \\
\text { and PU4 are the four indicators of PU. }\end{array}$ \\
\hline $\begin{array}{l}\text { Perceived } \\
\text { Credibility } \\
\quad \text { (PC) }\end{array}$ & $\begin{array}{l}\text { Hypothesis } 12 \text { (H12): Perceived credibility } \\
\text { positively impacts students' satisfaction } \\
\text { towards using the proctoring tool. }\end{array}$ & $\begin{array}{l}\text { The proctoring tool needs to provide } \\
\text { safety and security while using it. PC1, } \\
\text { PC2, and PC } 3 \text { are the indicators } \\
\text { specified for PC. }\end{array}$ \\
\hline $\begin{array}{l}\text { Academic } \\
\text { Performance } \\
\text { (AP) }\end{array}$ & $\begin{array}{l}\text { Hypothesis } 13 \text { (H13): Academic performance } \\
\text { positively impacts students' satisfaction } \\
\text { towards using the proctoring tool. } \\
\text { Hypothesis } 14 \text { (H14): Academic performance } \\
\text { positively impacts students' behavioral intense } \\
\text { to use the proctoring tool. }\end{array}$ & $\begin{array}{l}\text { AP is to measure the impact of online } \\
\text { proctoring on students' academic } \\
\text { grades. It has six indicators, AP1, AP2, } \\
\text { AP3, AP4, and AP5. }\end{array}$ \\
\hline
\end{tabular}




\begin{tabular}{|c|c|c|}
\hline $\begin{array}{l}\text { Use } \\
\text { satisfaction } \\
\quad \text { (US) }\end{array}$ & $\begin{array}{l}\text { Hypothesis } 15 \text { (H15): User satisfaction } \\
\text { positively impacts students' behavioral intense } \\
\text { to use the proctoring tool. }\end{array}$ & $\begin{array}{l}\text { The US construct is to understand how } \\
\text { the students felt and how satisfied they } \\
\text { were using the proctoring tool or } \\
\text { method. The three indicators are US1, } \\
\text { US2, and US3. }\end{array}$ \\
\hline $\begin{array}{l}\text { Facilitating } \\
\text { condition } \\
\text { (FC) }\end{array}$ & $\begin{array}{l}\text { Hypothesis } 16 \text { (H16): Facilitating condition } \\
\text { positively impacts students' satisfaction } \\
\text { towards using the proctoring tool. } \\
\text { Hypothesis } 17 \text { (H17): Facilitating condition } \\
\text { positively impacts students' acceptance of } \\
\text { using the proctoring tool. }\end{array}$ & $\begin{array}{l}\text { FC measures how students believe that } \\
\text { the institution provides support for } \\
\text { using the proctoring tool. The } \\
\text { indicators are from FC } 1 \text { to FC } 6 \text {. }\end{array}$ \\
\hline $\begin{array}{l}\text { Behavioral } \\
\text { intense to } \\
\text { use (BIU) }\end{array}$ & $\begin{array}{l}\text { Hypothesis } 18 \text { (H18): Behavioral intensity to } \\
\text { use positively impacts students' acceptance of } \\
\text { using the proctoring tool. }\end{array}$ & $\begin{array}{l}\text { BIU measures the intention to use the } \\
\text { proctoring tool in the coming future. } \\
\text { The indicators are BIU1, BIU2, and } \\
\text { BIU3. }\end{array}$ \\
\hline $\begin{array}{l}\text { Acceptance } \\
\text { to use (AU) }\end{array}$ & & $\begin{array}{l}\text { AU construct measures to find whether } \\
\text { students accept the proctoring tool in } \\
\text { the coming future, and the indicators } \\
\text { are AU1 and AU2. }\end{array}$ \\
\hline
\end{tabular}

\section{METHODOLOGY}

\section{Data Collection}

Based on the constructs from the previous section, we generated a collection of questionnaires. We concentrate on three types of proctoring: live human proctoring, AI proctoring, and blended proctoring. The survey is created using Google Forms. Data of a total of 478 students was collected. Among them, 126 are male students and 352 female students. The survey's participants are Kuwait University students, belonging to different colleges at Kuwait University like the College of Science, Engineering and Petroleum, Business Administration, Arts, Human Science, Law, College of Sharia and Islamic Studies, Education, Graduate Studies, and Social Science. All students who participated in the survey are guaranteed to take at least one online exam. The questions were set up on a Likert scale of one to five, with one denoting strongly disagree, and five indicating strongly agree.

\section{Evaluation Method}

The model is estimated using partial least square structured equation modeling (PLS-SEM). We use SmartPLS 3, which has many algorithms and modeling capabilities (Ringle et al., 2015; Sarstedt \& Cheah, 2019). The first step is to examine the measurement model for validity and reliability. The significance of path coefficients is reviewed in the second step, which is the structural model. The hypothesis is then evaluated based on these findings. Rho_A and composite reliability are used to assess the outer model's reliability, while the construct's average variance extracted 
(AVE) and discriminant validity are evaluated for validity. We looked at Rho_A, composite reliability values greater than 0.70, and AVE values greater than 0.5 (Cicha et al., 2021). For discriminant validity, the Fornell-Larcker criterion is checked (Wong, 2013). The significance of each build is then determined using the bootstrapping algorithm with path coefficients, p-values, confidence intervals, and t-values. The hypothesis is evaluated using a pvalue significant at a value less than 0.05 (Kock, 2016).

\section{RESULT}

\section{Data Analysis}

The participants' data is collected from the Google survey form and analyzed. The demographic data in Table 2 shows that the response rate is more from female students, which is $73.6 \%$, than that of $26.4 \%$ male students. Also, there are no missing values in the collected data. According to the proctoring method, year of study, and computer literacy, the complete response rate is shown in Table 2.

Table 2. Demographics of response rate.

\begin{tabular}{|c|c|c|c|}
\hline \multirow{2}{*}{ Category } & Factors/Variables & $\mathbf{N}$ & $\mathbf{\%}$ \\
\hline \multirow{3}{*}{ Gender } & Female & 352 & 73.6 \\
\cline { 2 - 4 } & Male & 126 & 26.4 \\
\hline \multirow{3}{*}{ Proctoring Method } & AI proctoring & 77 & 16.1 \\
\cline { 2 - 4 } & Live human proctoring & 220 & 46.0 \\
\cline { 2 - 4 } & Both AI and human proctoring & 181 & 37.9 \\
\hline \multirow{3}{*}{ Current year of study } & First-year & 113 & 23.6 \\
\cline { 2 - 4 } & Second-year & 103 & 21.5 \\
\cline { 2 - 4 } & Third-year & 110 & 23.0 \\
\cline { 2 - 4 } & Fourth-year & 103 & 21.5 \\
\cline { 2 - 4 } & Fifth-year & 49 & 10.3 \\
\hline \multirow{2}{*}{ Computer literacy } & Beginner & 267 & 55.9 \\
\cline { 2 - 4 } & Intermediate & 116 & 24.3 \\
\hline
\end{tabular}

Where $N=$ number of respondents or frequencies, $\%=$ percentage of respondents

In Table 3, the demographic data for proctoring method, year of study, and computer literacy are analyzed by gender. 
It shows that most students were proctored using live-human proctoring compared to AI and blended approaches. According to computer literacy, the total number of female students is 67 for beginner, 203 for intermediate, and 82 for expert. And in the case of male students, the count for beginner, intermediate, and expert are 28,64 , and 34, respectively. Figure 2 shows the data according to gender for each proctoring method with computer literacy.

Table 3. Demographic data by each category.

\begin{tabular}{|c|c|c|c|c|c|c|c|c|}
\hline $\begin{array}{l}\text { Proctoring } \\
\text { method }\end{array}$ & $\begin{array}{c}\text { Computer } \\
\text { literacy }\end{array}$ & Gender & $\begin{array}{l}\text { First } \\
\text { Year }\end{array}$ & $\begin{array}{c}\text { Second } \\
\text { Year }\end{array}$ & $\begin{array}{l}\text { Third } \\
\text { Year }\end{array}$ & $\begin{array}{c}\text { Fourth } \\
\text { Year }\end{array}$ & $\begin{array}{l}\text { Fifth } \\
\text { Year }\end{array}$ & Total \\
\hline \multirow{6}{*}{ 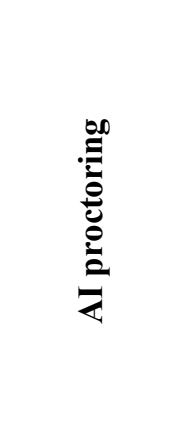 } & \multirow{2}{*}{ Beginner } & Female & 4 & 3 & 4 & 1 & 0 & \multirow{6}{*}{ 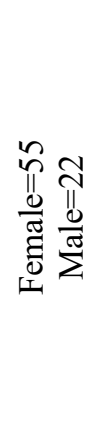 } \\
\hline & & Male & 1 & 2 & 0 & 0 & 0 & \\
\hline & \multirow{2}{*}{ Intermediate } & Female & 12 & 7 & 9 & 5 & 2 & \\
\hline & & Male & 6 & 7 & 1 & 0 & 2 & \\
\hline & \multirow{2}{*}{ Expert } & Female & 1 & 2 & 2 & 0 & 3 & \\
\hline & & Male & 0 & 0 & 1 & 1 & 1 & \\
\hline \multirow{6}{*}{ 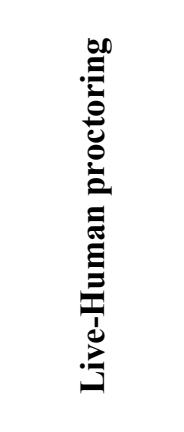 } & \multirow{2}{*}{ Beginner } & Female & 15 & 5 & 8 & 9 & 2 & \multirow{6}{*}{ 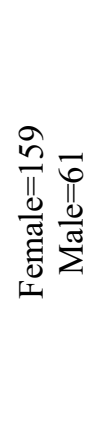 } \\
\hline & & Male & 1 & 7 & 3 & 0 & 3 & \\
\hline & \multirow{2}{*}{ Intermediate } & Female & 22 & 20 & 26 & 16 & 3 & \\
\hline & & Male & 7 & 12 & 7 & 8 & 0 & \\
\hline & \multirow{2}{*}{ Expert } & Female & 8 & 4 & 9 & 11 & 1 & \\
\hline & & Male & 0 & 5 & 2 & 3 & 3 & \\
\hline \multirow{6}{*}{ 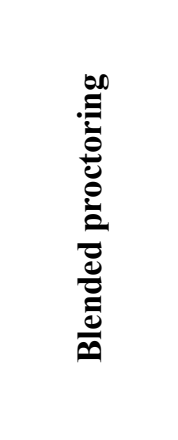 } & \multirow{2}{*}{ Beginner } & Female & 2 & 1 & 4 & 6 & 3 & \multirow{6}{*}{ 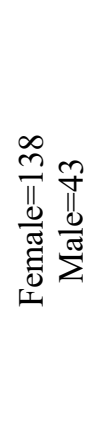 } \\
\hline & & Male & 5 & 1 & 0 & 3 & 2 & \\
\hline & \multirow{2}{*}{ Intermediate } & Female & 13 & 16 & 22 & 20 & 10 & \\
\hline & & Male & 3 & 2 & 5 & 3 & 1 & \\
\hline & \multirow{2}{*}{ Expert } & Female & 9 & 6 & 4 & 13 & 9 & \\
\hline & & Male & 4 & 3 & 3 & 4 & 4 & \\
\hline \multirow{2}{*}{\multicolumn{2}{|c|}{ Total }} & Female & 86 & 64 & 88 & 81 & 33 & 352 \\
\hline & & Male & 27 & 39 & 22 & 22 & 16 & 126 \\
\hline
\end{tabular}




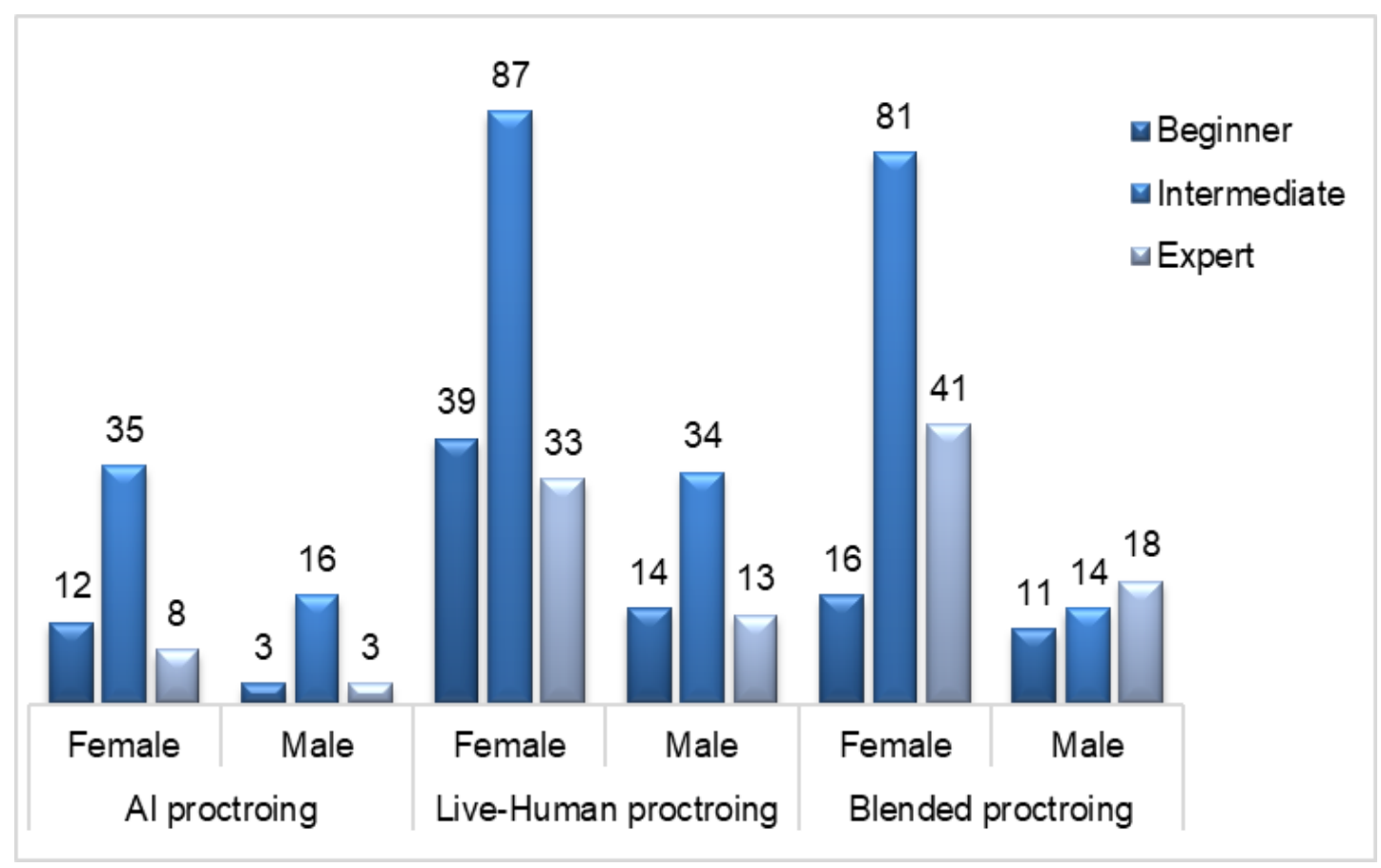

Figure 2. Demographic data by gender for proctoring method with computer literacy.

\section{Model Analysis}

The acceptance model is measured in two stages using PLS-SEM: the measurement model and the structural model. First, in the measurement model, PLS-Algorithm is executed, and it measured the Rho_A, composite reliability, AVE, and discriminant validity. Then, bootstrapping is done for the structural model, and path coefficient, p-value, and t-value are measured.

The composite reliability, rho_A, and AVE values are significant from the results. The indicators or items that show less significance are deleted and checked for AVE, whose values are not those of 0.5 , as shown in Table 4. For the academic integrity construct, the indicator AI2 is deleted in AI proctoring, and AI1 and AI2 are deleted in live-human and obtained an AVE value greater than 0.5. Academic integrity and facilitating condition have an AVE of less than 0.5 in the blended method. As a result, eliminating the unimportant indication, AI2, AI3, FC3, and FC4 results in an AVE value greater than 0.5. There is no difference in significance for hypothesis testing by deleting the indicators, so all items are taken for analysis. 
Table 4. Measurement model assessment.

\begin{tabular}{|c|c|c|c|c|c|c|c|c|c|}
\hline \multirow{2}{*}{ Constructs } & \multicolumn{3}{|c|}{ rho_A } & \multicolumn{3}{|c|}{ Composite Reliability } & \multicolumn{3}{|c|}{$\begin{array}{l}\text { Average Variance } \\
\text { Extracted (AVE) }\end{array}$} \\
\hline & AI & Live & $\begin{array}{l}\text { Blend } \\
\text { ed }\end{array}$ & $\mathbf{A I}$ & Live & $\begin{array}{c}\text { Blend } \\
\text { ed }\end{array}$ & AI & Live & $\begin{array}{c}\text { Blend } \\
\text { ed }\end{array}$ \\
\hline $\begin{array}{l}\text { Academic } \\
\text { Integrity }\end{array}$ & 0.697 & 0.583 & 0.620 & 0.697 & 0.708 & 0.656 & 0.402 & 0.354 & 0.360 \\
\hline $\begin{array}{c}\text { Academic } \\
\text { Performance }\end{array}$ & 0.797 & 0.825 & 0.842 & 0.842 & 0.840 & 0.842 & 0.524 & 0.524 & 0.536 \\
\hline $\begin{array}{c}\text { Acceptance to } \\
\text { Use }\end{array}$ & 0.317 & 0.716 & 0.544 & 0.741 & 0.875 & 0.813 & 0.590 & 0.778 & 0.685 \\
\hline $\begin{array}{c}\text { Attitude } \\
\text { Towards } \\
\text { Usage } \\
\end{array}$ & 0.869 & 0.866 & 0.848 & 0.669 & 0.698 & 0.716 & 0.596 & 0.551 & 0.625 \\
\hline $\begin{array}{l}\text { Behavioral } \\
\text { Intense to Use }\end{array}$ & 0.761 & 0.849 & 0.831 & 0.836 & 0.904 & 0.891 & 0.630 & 0.760 & 0.734 \\
\hline Exam Time & 0.855 & 0.999 & 0.829 & 0.736 & 0.742 & 0.769 & 0.523 & 0.513 & 0.546 \\
\hline $\begin{array}{l}\text { Facilitating } \\
\text { Condition }\end{array}$ & 0.817 & 0.864 & 0.764 & 0.860 & 0.880 & 0.813 & 0.507 & 0.554 & 0.429 \\
\hline $\begin{array}{l}\text { Perceived } \\
\text { Credibility }\end{array}$ & 0.971 & 0.978 & 0.960 & 0.955 & 0.930 & 0.931 & 0.876 & 0.815 & 0.819 \\
\hline $\begin{array}{l}\text { Perceived } \\
\text { Usefulness }\end{array}$ & 0.737 & 0.785 & 0.789 & 0.830 & 0.841 & 0.844 & 0.553 & 0.576 & 0.580 \\
\hline $\begin{array}{l}\text { System } \\
\text { Concern }\end{array}$ & 0.997 & 0.840 & 0.846 & 0.895 & 0.892 & 0.906 & 0.740 & 0.733 & 0.763 \\
\hline Test Anxiety & 1.000 & 1.000 & 1.000 & 1.000 & 1.000 & 1.000 & 1.000 & 1.000 & 1.000 \\
\hline $\begin{array}{c}\text { User } \\
\text { Satisfaction }\end{array}$ & 0.722 & 0.721 & 0.744 & 0.787 & 0.842 & 0.854 & 0.575 & 0.643 & 0.662 \\
\hline
\end{tabular}

Figure 3 shows the complete assessment of the model with outer loadings of the items, path coefficients within the constructs, and the AVE of each construct. Figure 3 (a) depicts the AI proctoring method assessment, (b) for the live-human method, and (c) blended proctoring. 


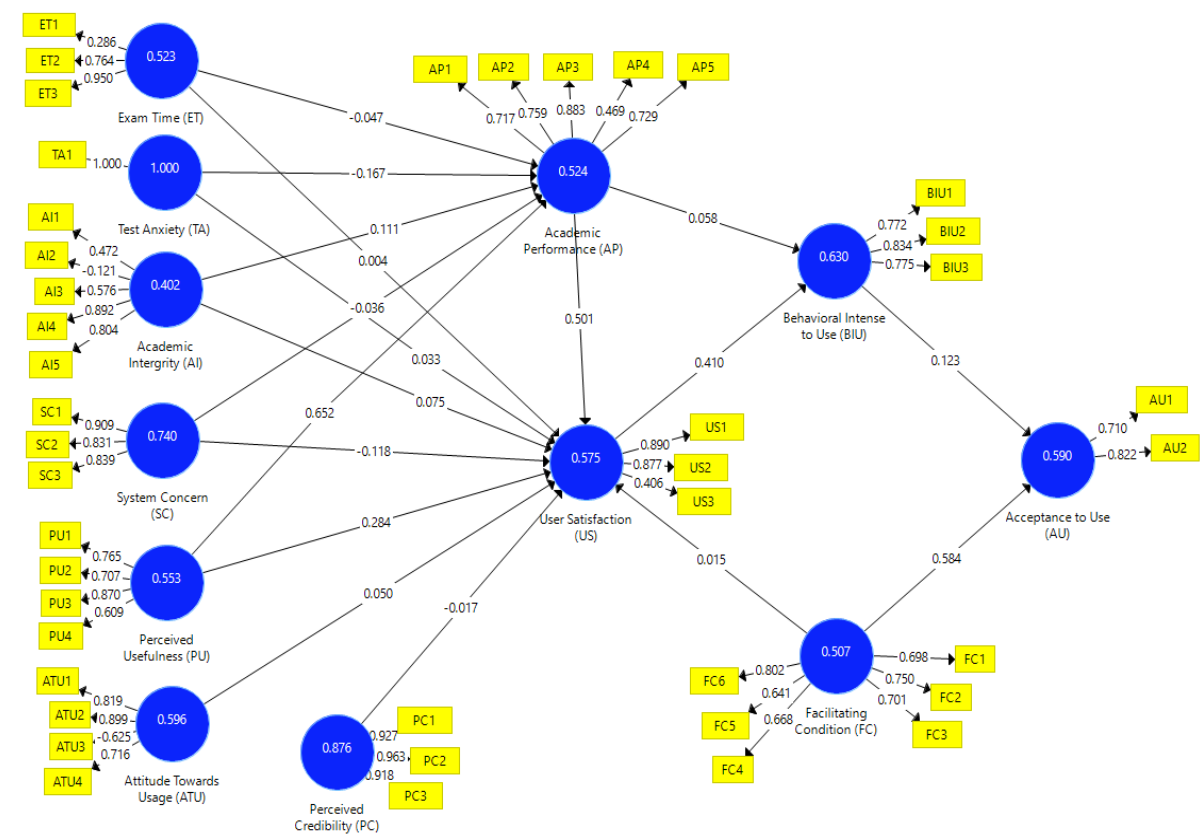

(a)

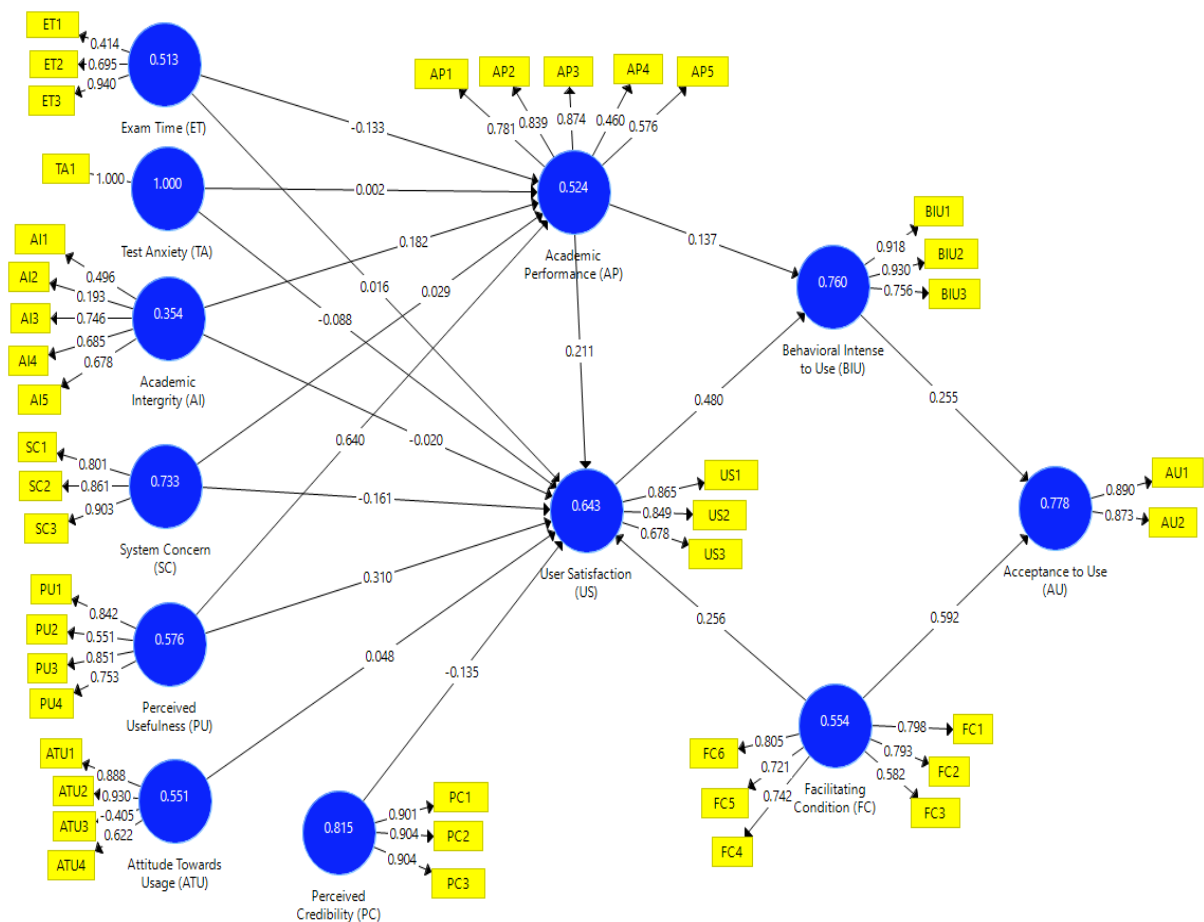

(b) 


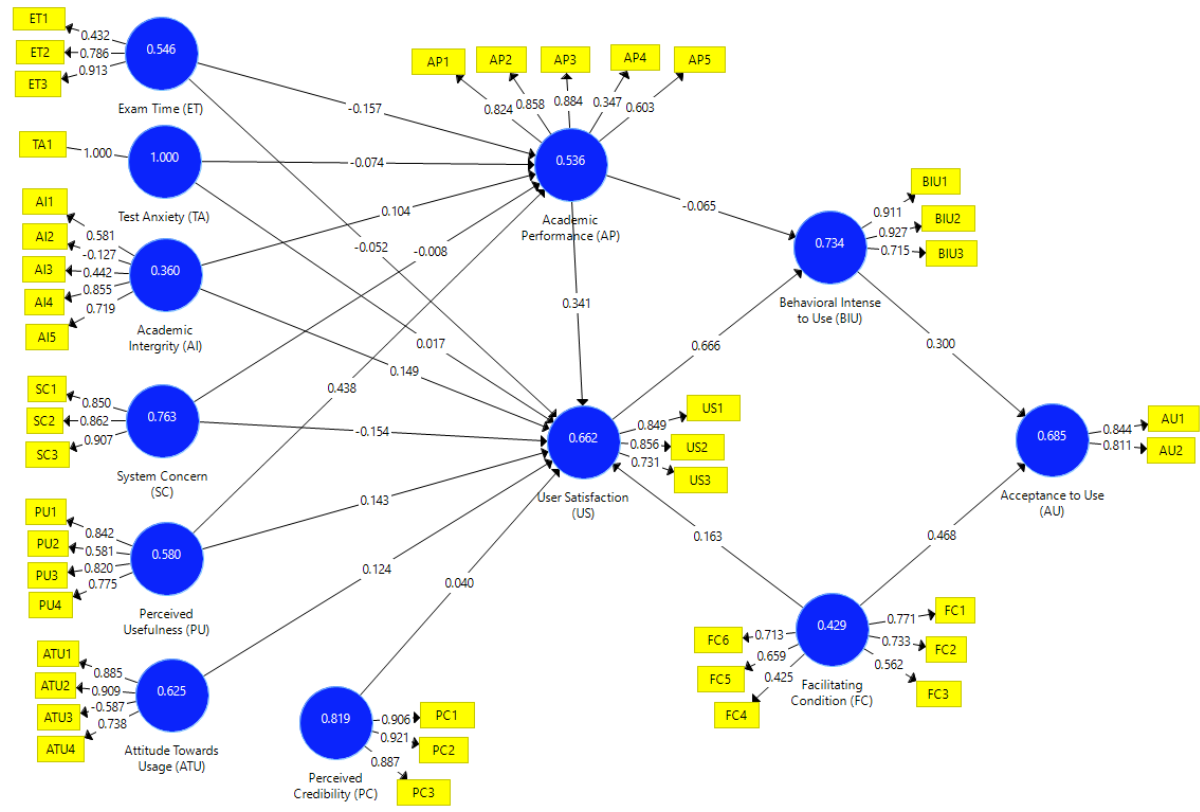

(c)

Figure 3. Assessment model: (a) AI-proctoring method. (b) Live-human proctoring. (c) Blended proctoring.

Table 5 shows the structural assessment according to the three different proctoring methods. Here, the p-value is used to evaluate the hypothesis testing. Most of the hypotheses are insignificant in AI proctoring method compared to blended and live-human proctoring.

Table 5. Structural model assessment.

\begin{tabular}{|c|c|c|c|c|c|c|c|}
\hline \multirow{2}{*}{ Hypotheses } & \multirow{2}{*}{ Constructs } & \multicolumn{3}{|c|}{ P-value } & \multicolumn{3}{c|}{ Decision } \\
\cline { 3 - 8 } & & AI & Live & Blended & AI & Live & Blended \\
\hline H1 & ET -> AP & 0.609 & 0.028 & 0.113 & Insignificant & Significant & Insignificant \\
\hline H2 & ET -> US & 0.956 & 0.775 & 0.383 & Insignificant & Insignificant & Insignificant \\
\hline H3 & TA -> AP & 0.059 & 0.942 & 0.257 & $\begin{array}{c}\text { Moderately } \\
\text { significant }\end{array}$ & Insignificant & Insignificant \\
\hline H4 & TA -> US & 0.639 & 0.178 & 0.778 & Insignificant & Insignificant & Insignificant \\
\hline H5 & AI -> AP & 0.355 & 0.001 & 0.173 & Insignificant & Significant & Insignificant \\
\hline
\end{tabular}




\begin{tabular}{|c|c|c|c|c|c|c|c|}
\hline H6 & AI $->$ US & 0.630 & 0.866 & 0.012 & Insignificant & Insignificant & Significant \\
\hline H7 & $\mathrm{SC}->\mathrm{AP}$ & 0.695 & 0.628 & 0.959 & Insignificant & Insignificant & Insignificant \\
\hline H8 & $\mathrm{SC}->\mathrm{US}$ & 0.175 & 0.018 & 0.008 & Insignificant & Significant & Significant \\
\hline H9 & $\begin{array}{c}\text { ATU -> } \\
\text { US }\end{array}$ & 0.721 & 0.457 & 0.051 & Insignificant & Insignificant & Significant \\
\hline H10 & $\mathrm{PU}->\mathrm{AP}$ & 0.000 & 0.000 & 0.000 & Significant & Significant & Significant \\
\hline H11 & PU -> US & 0.038 & 0.000 & 0.025 & Significant & Significant & Significant \\
\hline H12 & $\mathrm{PC}->\mathrm{US}$ & 0.982 & 0.022 & 0.523 & Insignificant & Significant & Insignificant \\
\hline H13 & AP $->$ US & 0.007 & 0.019 & 0.000 & Significant & Significant & Significant \\
\hline H14 & AP $->$ BIU & 0.993 & 0.186 & 0.461 & Insignificant & Insignificant & Insignificant \\
\hline H15 & US-> BIU & 0.084 & 0.000 & 0.000 & Insignificant & Significant & Significant \\
\hline H16 & $\mathrm{FC}->\mathrm{US}$ & 0.925 & 0.007 & 0.040 & Insignificant & Significant & Significant \\
\hline H17 & $\mathrm{FC}->\mathrm{AU}$ & 0.000 & 0.000 & 0.000 & Significant & Significant & Significant \\
\hline H18 & BIU -> AU & 0.320 & 0.000 & 0.000 & Insignificant & Significant & Significant \\
\hline
\end{tabular}

\section{DISCUSSION}

In this study, a total of eighteen hypotheses were formulated and tested on each proctoring method, namely, AI proctoring, Live-human proctoring, and Blended proctoring, from the response among 478 students. The results show that $46 \%$ of the students were proctored using live-human method than the blended method (37.9\%). However, even these proctoring methods reduce the chance of cheating during exams, they cannot wholly eradicate it. Around $60 \%$ of the students who participated have better computer knowledge.

In all the measurement model assessments for AVE to have a value higher than 0.5, an indicator less significant is deleted (Hair et al., 2019), and then, the bootstrapping step is done. But it does not affect the final results, so all items are kept for evaluation. In AI proctoring, the hypotheses H3, H10, H11, H13, and H17 are significant. The students believe that ET during online learning negatively affects their academic and satisfaction to use the proctoring tool. At the same time, the perception of the proctoring method's usefulness is high during the online exam. The majority of hypotheses are supported during the live-human proctoring phase. The students' opinions on their 
teachers' usage of the proctoring technique are generally recognized. However, their attitude towards using the tool is not satisfactory. In the blended proctoring method, the hypotheses for ET, TA, and SC are insignificant. During AI and hybrid techniques, the safety of proctoring methods is not recognized. It may be due to students' reluctance to record their videos while being proctored. Nevertheless, with all proper resources and knowledge of using the proctoring tool and appropriate support for technical issues, most students are delighted compared to the traditional face-to-face proctoring.

According to the students, misconduct during online tests cannot be managed entirely using the proctoring options, and they are dissatisfied. Most of them have technical problems with the system during the exam. Anxiety is another concern for some of the students. Professors need to motivate students and help them reduce their anxiety. The time taken for the exam is another factor when the students consider their academic performance. Some measures like practicing exams, taking feedback, or gaining experience from the students after the exam need to be considered by the professors, reducing the students' stress and anxiety.

The study also collects some measures that the students feel can reduce cheating during exams.

Figure 4 shows the steps to minimize cheating during exams. Some of them are shuffling of questions, reducing the time limits, more application type questions, a combination of descriptive and computational questions, another form of assessments like projects, grading with attendance, and oral exams. Most of the students prefer shuffling of questions and another evaluation method. Also, the use of a proctoring tool is widely accepted.

Furthermore, students were given an open-ended inquiry regarding their feelings about proctoring. The majority of students believed that there was insufficient time for examinations and that cheating levels did not decrease. Distance education is suitable and successful, but the exam time is limited, preventing them from doing the exam comfortably and with attention, negatively impacting their grades. Compared to live-human and blended proctoring, the AI method makes students more stressed.

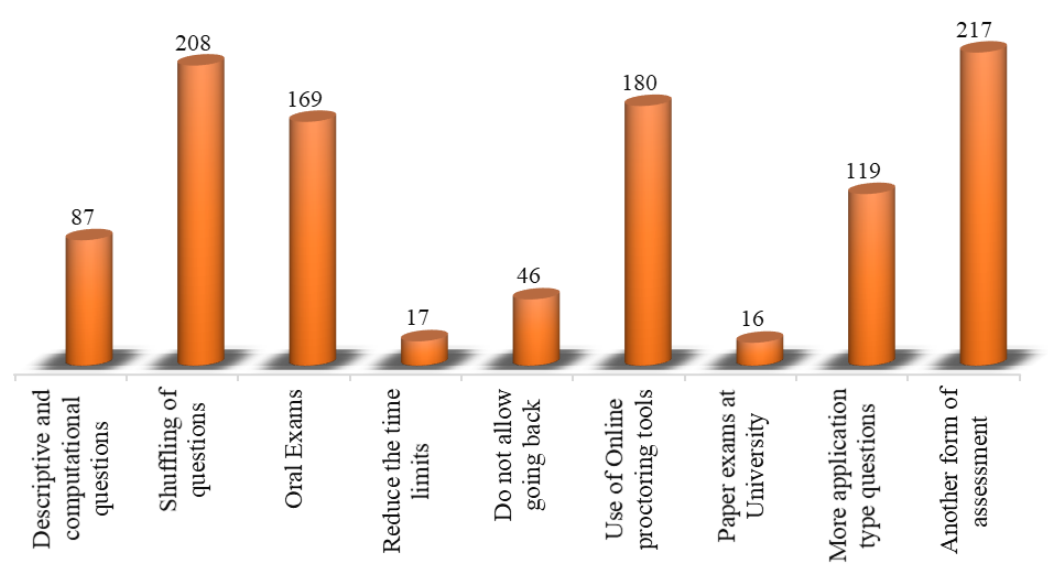

Figure 4. Some measures to reduce cheating preferred by students.

\section{CONCLUSION}

How to effectively verify the legitimacy and effectiveness of online programs will remain a challenge for educational institutions. Trusted proctoring solutions have become critical tools in online education. In both face-toface and online tests, cheating has always existed and will continue to exist. We should try to keep it at a roughly balanced state. This study aims to understand the student's preference and satisfaction with proctoring method during 
online exams at the COVID-19 pandemic. The AI method, when compared to live-human and blended proctoring, causes students to be more worried. The factors like time, anxiety, and some technical problems during the exam need to be considered in the proctoring environment. Moreover, the students are satisfied in using the live-human and blended proctoring techniques.

Future studies include collecting more data from participants of other colleges and universities in Gulf countries. Because our current study only involves students as participants, we can also incorporate the viewpoint of teachers or professors. Also, comparing the results with the male and female group of participants can be another future enhancement.

\section{ACKNOWLEDGMENT}

The Kuwait Foundation for Advancement of Sciences (KFAS) supported this study with Grant Number CORONA 105/ PN20-19TM-15.

\section{APPENDIX A}

The demographic details of the participants associated with this study can be found in the online link: https://bit.ly/31p4Wzm.

The data for model analysis associated with this study can be found in the online link: https://bit.ly/3DpYvlY.

\section{REFERENCES}

Al-Maroof, R. S., Alshurideh, M. T., Salloum, S. A., AlHamad, A. Q. M., \& Gaber, T. (2021). Acceptance of Google Meet during the spread of Coronavirus by Arab university students. Informatics,

Ali, L., \& Al Dmour, N. A. H. H. (2021). The Shift to Online Assessment Due to COVID-19: An Empirical Study of University Students, Behaviour and Performance, in the Region of UAE. International Journal of Information and Education Technology, 11(5).

Alkamel, M. A. A., Chouthaiwale, S. S., Yassin, A. A., AlAjmi, Q., \& Albaadany, H. Y. (2021). Online Testing in Higher Education Institutions During the Outbreak of COVID-19: Challenges and Opportunities. Emerging Technologies During the Era of COVID-19 Pandemic, 348, 349.

Arora, S., Chaudhary, P., \& Singh, R. (2021). Impact of coronavirus and online exam anxiety on self-efficacy: the moderating role of coping strategy. Interactive Technology and Smart Education, ahead-of-print. https://doi.org/10.1108/ITSE-08-2020-0158

Cahapay, M. B. (2021). Problems Encountered by College Students in Online Assessment Amid COVID-19 Crisis: A Case Study. International Journal of Computer Science and Information Technology for Education.

Chuang, C.-Y., Craig, S. D., \& Femiani, J. (2015). The Role of Certainty and Time Delay in Students' Cheating Decisions during Online Testing. CogSci,

Cicha, K., Rizun, M., Rutecka, P., \& Strzelecki, A. (2021). COVID-19 and higher education: first-year students' expectations toward distance learning. Sustainability, 13(4), 1889. 
Davis, A. B., Rand, R., \& Seay, R. (2016). Remote proctoring: The effect of proctoring on grades. In Advances in accounting education: Teaching and curriculum innovations. Emerald Group Publishing Limited.

Dendir, S., \& Maxwell, R. S. (2020). Cheating in online courses: Evidence from online proctoring. Computers in Human Behavior Reports, 2, 100033.

Driscoll, R. (2007). Westside Test Anxiety Scale Validation. Online submission.

Fattah, A., \& Setyadi, R. (2021). Determinants Effectiveness Information Technology Governance in Higher Education Institution (HEI) using partial least squares structural equation modeling approach (PLS-SEM). Journal of Physics: Conference Series,

Foster, D., \& Layman, H. (2013). Online proctoring systems compared. Webinar. http://www.slideshare.net/caveonweb/caveon-webinar-series-online-proctoring-best-practicesoct-2013slideshare-final

Gamage, K. A. A., Silva, E. K. d., \& Gunawardhana, N. (2020). Online Delivery and Assessment during COVID-19: Safeguarding Academic Integrity. Education Sciences, 10(11), 301. https://www.mdpi.com/2227-7102/10/11/301

Goldberg, D. (2021). Programming in a Pandemic: Attaining Academic Integrity in Online Coding Courses. Communications of the Association for Information Systems, 48(1), 6.

Hair, J. F., Risher, J. J., Sarstedt, M., \& Ringle, C. M. (2019). When to use and how to report the results of PLS-SEM. European business review.

Hair Jr, J. F., Sarstedt, M., Hopkins, L., \& Kuppelwieser, V. G. (2014). Partial least squares structural equation modeling (PLS-SEM): An emerging tool in business research. European business review.

Hollister, K. K., \& Berenson, M. L. (2009). Proctored versus unproctored online exams: Studying the impact of exam environment on student performance. Decision Sciences Journal of Innovative Education, 7(1), 271-294.

Howard, D. (2020). Comparison of Exam Scores and Time Taken on Exams Between Proctored On-Campus and Unproctored Online Students. Online Learning, 24(4).

Hussein, M. J., Yusuf, J., Deb, A. S., Fong, L., \& Naidu, S. (2020). An evaluation of online proctoring tools (Vol. 12). International Council for Open and Distance Education. https://doi.org/10.3316/informit.620366163696963

Ikram, F., \& Rabbani, M. A. (2021). Academic Integrity in Traditional Vs Online Undergraduate Medical Education Amidst COVID-19 Pandemic. Cureus, 13(3).

Ismail, R., Osmanaj, V., \& Jaradat, A. (2019). MOVING TOWARDS E-UNIVERSITY: MODELLING THE ONLINE PROCTORED EXAMS.

Kamble, K. P., \& Ghorpade, V. R. (2021). Video Interpretation for Cost-Effective Remote Proctoring to Prevent Cheating. Proceeding of First Doctoral Symposium on Natural Computing Research,

Kock, N. (2016, 07/01). Hypothesis Testing with Confidence Intervals and P Values in PLS-SEM. International Journal of e-Collaboration, 12, 1-6. https://doi.org/10.4018/IJeC.2016070101 
Le Corff, Y., Gingras, V., \& Busque-Carrier, M. (2017). Equivalence of unproctored internet testing and proctored paper-and-pencil testing of the Big Five. International Journal of Selection and Assessment, 25(2), 154-160.

Lee, Y., Kozar, K. A., \& Larsen, K. R. (2003). The technology acceptance model: Past, present, and future. Communications of the Association for Information Systems, 12(1), 50.

Li, H., Xu, M., Wang, Y., Wei, H., \& Qu, H. (2021). A Visual Analytics Approach to Facilitate the Proctoring of Online Exams. arXiv preprint arXiv:2101.07990.

Medina, M. S., \& Castleberry, A. N. (2016). Proctoring strategies for computer-based and paper-based tests. American Journal of Health-System Pharmacy, 73(5), 274-277. https://doi.org/10.2146/ajhp150678

Mutawa, A.M., \& Sruthi, Sai. (2021), Online Proctoring and Assessment in Distance Learning During COVID-19, EDULEARN21, pp. 5887-5895.

Muzaffar, A. W., Tahir, M., Anwar, M. W., Chaudry, Q., Mir, S. R., \& Rasheed, Y. (2021). A Systematic Review of Online Exams Solutions in E-Learning: Techniques, Tools, and Global Adoption. IEEE Access, 9, 32689-32712. https://doi.org/10.1109/ACCESS.2021.3060192

Organization, W. H. (2020). Coronavirus. https://www.who.int/emergencies/diseases/novel-coronavirus-2019

Ringle, C., Wende, S., \& Becker, J.-M. (2015). SmartPLS 3, Bönningstedt: SmartPLS.

Salimon, M. G., Sanuri, S. M. M., Aliyu, O. A., Perumal, S., \& Yusr, M. M. (2021). E-learning satisfaction and retention: a concurrent perspective of cognitive absorption, perceived social presence and technology acceptance model. Journal of Systems and Information Technology.

Sando, K., Medina, M. S., \& Whalen, K. (2021). The Need for New Guidelines and Training for Remote/Online Testing and Proctoring Due to COVID-19. American Journal of Pharmaceutical Education.

Sarstedt, M., \& Cheah, J.-H. (2019, 2019/09/01). Partial least squares structural equation modeling using SmartPLS: a software review. Journal of Marketing Analytics, 7(3), 196-202. https://doi.org/10.1057/s41270-019-00058-3

Shahzad, A., Hassan, R., Aremu, A. Y., Hussain, A., \& Lodhi, R. N. (2021). Effects of COVID-19 in Elearning on higher education institution students: the group comparison between male and female. Quality \& quantity, 55(3), 805-826.

Slusky, L. (2020). Cybersecurity of Online Proctoring Systems. Journal of International Technology and Information Management, 29(1), 56-83.

Stapleton, P., \& Blanchard, J. (2021). Remote Proctoring: Expanding Reliability and Trust. Proceedings of the 52nd ACM Technical Symposium on Computer Science Education,

Tiong, L. C. O., \& Lee, H. J. (2021). E-cheating Prevention Measures: Detection of Cheating at Online Examinations Using Deep Learning Approach--A Case Study. arXiv preprint arXiv:2101.09841.

Vazquez, J. J., Chiang, E. P., \& Sarmiento-Barbieri, I. (2021). Can we stay one step ahead of cheaters? A field experiment in proctoring online open book exams. Journal of Behavioral and Experimental Economics, 90, 101653. 
Weiner, J. A., \& Hurtz, G. M. (2017). A comparative study of online remote proctored versus onsite proctored high-stakes exams. Journal of Applied Testing Technology, 18(1), 13-20.

Woldeab, D., \& Brothen, T. (2019). 21st Century assessment: Online proctoring, test anxiety, and student performance.

Wong, K. (2013, 01/01). Partial least square structural equation modeling (PLS-SEM) techniques using SmartPLS. Marketing Bulletin, 24, 1-32. 